\title{
Support of Desi cows in the daily livelihood of farm households in Karnataka
}

\author{
DV Kolekar ${ }^{1}$, MJ Chandre Gowda ${ }^{2}$ and CV Sairam ${ }^{3}$
}

Received: 10 July 2021 / Accepted: 24 August 2021 / Published online: 31 October 2021

(C) Indian Dairy Association (India) 2021

\begin{abstract}
Desi cows along with crossbred have major contribution in fulfilling the demand of milk by the growing population of India. Achieving food security, nutrition security and income security for the farmers and by the farmers is a priority concern of national and state governments in India. In order to fulfill the national goal of doubling farmers income by 2022, animal husbandry in general and dairy farming in particular are considered as potential activities. In this backdrop, the present study was carried out in six districts of Karnataka based on higher population of desi cows with a sample size of 240 farm households. The study revealed that the sample households had more number of milking desi cows as compared to crossbred cows. Average quantity of green fodder and concentrates fed per animal in case of desi cows was less compared to crossbred cows. Thus, total feed cost and expenditure per animal was less in case of desi cows than crossbred cows. Desi cows required less expenditure on health per day/anim., but the net return per animal, per farm and per liter was less in desi cows due to low productivity as compared to crossbred cows. Crossbred cows supplied more nutrients to farm i.e. NPK kg/year/animal compared to desi cows. However, protein, fat and calcium nourishment per animal to the family was more in case of desi cows as compared to crossbred cows. Employment generation (mandays/year) per animal was more in case of crossbred cows as compared to indigenous cows. Security for uncertainties and status symbol was more in case of crossbred cows as compared to desi cows.
\end{abstract}

\footnotetext{
${ }^{1 \& 2}$ ICAR-Agricultural Technology Application Research Institute MRS, H A Farm Post, Hebbal, Bengaluru-560024

${ }^{3}$ ICAR-CIBA, Chennai

DV Kolekar ( $\square)$

ICAR-Agricultural Technology Application Research Institute, MRS, H A Farm Post, Hebbal, Bengaluru-560024

Email: drdnyanesh45@gmail.com
}

Keywords: Desi cows, Crossbred cows, Dairy farming, Livelihood.

\section{Introduction}

Livestock plays an important role in Indian economy. About 20.5 million people depend upon livestock for their livelihood. Livestock provides livelihood to two-third of rural community. It also provides employment to about $8.8 \%$ of the population in India. India has vast livestock resources. Livestock sector contributes $4.11 \%$ GDP and $25.6 \%$ of total Agriculture GDP. India is World's highest livestock owner at about 535.78 million. Out of this 192.49 million is cattle population i.e. 151 million desi and 39.732 million crossbred cows. In 2017-18, Indian dairy sector produced 176.3 million tons of milk. The per capita availability of milk has also increased from 112 grams per day in 1968-69 to 290 grams per day in 2017-18 (Basic Animal Husbandry Statistics, 2018). Cows have major contribution in the fulfilling the demand of milk by the growing population of India.

Most of the desi cows (about 80\%) are non- descript and only 20 per cent belong to desi breeds. Desi cows are considered to be robust and resilient and are particularly suited to the climate and environment of their respective breeding tracts. They are endowed with qualities of heat tolerance, resistance to diseases and the ability to thrive under extreme climatic stress and less than optimal nutrition (GOI, 2014). Most of the desi cows possess A2 allele of beta casein as compared to crossbred cows. Reportedly A1 milk is associated with some metabolic disorders like diabetes, heart diseases etc., whereas, A2 milk from desi breeds does not have any such association. Cow is a source of subsidiary income for many families in India especially the resource poor who maintain few heads of animals.

In Karnataka, more than 60 per cent of its population lives in rural areas and depends on agriculture for their source of income (Government of Karnataka, Census, 2011). Nearly 90 per cent of the population in the semi-arid region depends on agriculture for livelihood and livestock rearing as subsidiary occupation. In difficult situations, livestock, especially desi cows rescue the farmers from economic crisis. During drought and hot environmental conditions desi cows are reported to thrive on 
poor quality roughages and acts as the buffer in the crisis. Therefore, it becomes essential to know the exact role played by desi and crossbred cows in the livelihood of resource poor farmers. Considering the above facts, present study entitled "Support of Desi Cows in the daily livelihood of farm households in Karnataka" was undertaken.

\section{Materials and Methods}

As per National Bureau of Animal Genetics Resources (2020), there are six desi cows breeds in Karnataka, namely; Amrithmahal, Deoni, Hallikar, Khillari, Krishna Valley and Malnad Gidda along with good number of crossbred cows population. So, the present study was carried out purposively in Karnataka. The sampling scheme adopted for this study was three-stage stratified random sampling without replacement. The study was conducted in six districts of Karnataka based on highest population of desi cows. From each of the selected districts, two taluks were selected based on highest density of desi and crossbred cows in that locality, as per the secondary data. From each of the selected taluk, based on similar criteria, a cluster of three village panchayats and a total of 36 village panchayats formed the study area. From each selected cluster of villages, 20 households owning desi and crossbred cows and from each selected household, one adult member or head of the household actively engaged in management of desi and crossbred cows was considered as the respondent. Thus, 20 cow owners from each cluster of villages, made a total of cow owners sample size to 240 .

The data were collected through semi-structured interview schedule. The respondents were asked to give information on milk production and livelihood security parameters. The data so collected were analyzed for estimating the costs, returns from milk production and contribution in livelihood security of farmers from desi and crossbred cows. The returns were calculated over variable cost i.e. gross margin. The statistical significance of differences in milk production parameters were tested by using ' $z$ ' test with the help of SPSS software. Livelihood security is operationalized as contribution made by desi and crossbred cows in terms of income generation, nourishment to the family, nutrients to farm, employment generation, security during uncertainties and social status symbol. The index developed by Biradar et al (2013) was used with required modifications as given below:

- Contribution to the total household income: The net return was measured by collecting information on different production values of each cow and average values of each parameter were calculated.

- Nourishment to the family: Based on the daily average milk consumed by the family, the nutrients were computed in terms of protein, fat and calcium as suggested by Gopalan et al. (1971).

- Nutrients to the farm: The average farm yard manure applied to their respective farm was converted in terms of $\mathrm{N}, \mathrm{P}$ and $\mathrm{K}$ by following the conversion factors suggested by Gautam (2007), that is, one ton of farm yard manure was equivalent to $8 \mathrm{Kg} \mathrm{N}, 4 \mathrm{Kg} \mathrm{P}_{2} \mathrm{O}_{5}$ and 16 $\mathrm{Kg} \mathrm{K}_{2} \mathrm{O}$.

- Employment generation: Number of hours engaged in desi and crossbred cows rearing for one year were collected. Total hours spent in a year were divided by 8 hours to convert them in to man-days. Total number of man-days contributed was expressed as mean values.

- Security during uncertainties: Number of households having used desi and crossbred cows to face the uncertainties in the past two years.

- Status symbol: The number of households who regard keeping desi and crossbred cows as symbol of social status.

\section{Results and Discussion}

To ascertain role of desi and crossbred cows in dairy production of farmers, the average values of some of the milk production parameters were calculated and are presented in Table 1. Sample households had more number of milking desi cows (2.03) as compared to crossbred cows (1.66). Average quantity of green fodder and concentrates fed per animal in case of desi cows was $9.82 \& 0.83 \mathrm{~kg}$ respectively. This was less as compared to crossbred cows (17.47 \& $3.11 \mathrm{~kg}$ resp.). Although average quantity of dry fodder fed per animal in case of desi cows was more $(7.13 \mathrm{~kg})$ as compared to crossbred cows $(7.06 \mathrm{~kg})$, total feed cost and expenditure per animal was less in case of desi cows (Rs.56.61 \& 67.11 resp.) than crossbred cows (Rs.104.13 \& 138.11 respectively). In all the cases, desi cows were producing less milk (2.86 L/day) as compared to crossbred cows $(6.83 \mathrm{~L} /$ day $)$. Desi cows required less expenditure on health per day/anim. (Rs.0.5) but the net return/day per animal (Rs.12.98) was less due to low productivity as compared to crossbred cows (Rs.53.10).

Majority of the cows owners used own farm grown dry and green fodder to feed their cows or from grazing. Also, dung produced ( $19.45 \& 25.23 \mathrm{Kg} /$ day/anim. in case of desi \& crossbred cows) was used as manure for his/her own farm including draught power ( $1.95 \& 0.03 \mathrm{hrs} /$ day in case of desi \& crossbred cows). Milk for nourishment to family was higher from desi breeds (1.40 $\mathrm{L} /$ day) as compared to crossbred cows $(0.19 \mathrm{~L} /$ day). Without considering cost of fodder as shown in Table 1, total feed cost (Rs/anim./day) was less in case of desi cows (13.35) as compared to crossbred cows (49.70). Thus, total expenditure (Rs/anim./ day) was less in case of desi cows (23.85) as compared to crossbred cows (83.68). Net return/day per animal (Rs.56.24) was less in case of desi cows due to low productivity as compared to crossbred cows (Rs. 107.53).

Similarly, contribution of dairy animals in Western Maharashtra has been assessed by Kolekar et al. (2015), wherein gross return per animal, per farm and per liter was more in case of private dairy farmers as compared to cooperative dairy farmers. The ' $z$ ' test 
was used to test the difference between the milk production parameters perceived for desi and crossbred cows. Analysis showed that there was a significant difference between all the milk production parameters of two cow breeds.

To ascertain contribution of desi and crossbred cows to the farmers livelihood, the average values of the types of contribution were calculated and presented in Table 2. From the Table 2, it is clear that net return/day per animal (Rs.12.98), per farm (Rs.27.18) and per liter (Rs.3.00) was less in desi cows due to low productivity as compared to crossbred cows (Rs. 53.10,91.62 \& 5.69 resp.). Majority of the cows owners used own farm grown dry and green fodder to feed their cows or from grazing. Also, dung produced was used as manure for his own farm including draught power \& some milk for nourishment to family. Protein, fat and calcium nourishment per animal to the family (gm/day) was less in case of crossbred cows $(5.92,7.59 \& 0.22$, respectively) as compared to desi cows $(44.90,57.52 \& 1.68$, respectively). Nutrients supply to farm i.e. NPK $\mathrm{kg} /$ year/animal was more in case of crossbred cows $(73.66,36.83 \& 147.33$, respectively) as compared to desi cows $(56.79,28.40 \& 113.59$, respectively). Employment generation (mandays/year) per animal was more in case of crossbred cows (80.02) as compared to desi cows (42.34).

Table 1 Milk production parameters of desi vs crossbred cows perceived by households

\begin{tabular}{|c|c|c|c|c|c|}
\hline \multirow[t]{2}{*}{ Parameter } & \multicolumn{2}{|c|}{ Desi Cows } & \multicolumn{2}{|c|}{ Crossbred Cows } & \multirow[t]{2}{*}{$P$ value } \\
\hline & $\overline{\text { Mean }}$ & SD & Mean & $\mathrm{SD}$ & \\
\hline Total milking animals (no.) & 2.03 & 1.80 & 1.66 & 1.29 & 0.008 \\
\hline Total milk production (L/day) & 5.85 & 5.57 & 11.55 & 10.78 & 0.000 \\
\hline Total milk production (L/anim./day) & 2.86 & 0.69 & 6.83 & 1.25 & 0.000 \\
\hline Total dry fodder fed (kg/anim./day) & 7.13 & 2.42 & 7.06 & 2.05 & 0.001 \\
\hline Total daily green fodder fed ( $\mathrm{kg} /$ anim./day) & 9.82 & 4.39 & 17.47 & 5.39 & 0.001 \\
\hline Total concentrate fed (kg/anim./day) & 0.83 & 0.51 & 3.11 & 0.79 & 0.000 \\
\hline Total feed cost (Rs/anim.) & 56.61 & 14.66 & 104.13 & 18.51 & 0.013 \\
\hline Labour cost (Rs/anim./day) & 10.00 & $.000 \mathrm{a}$ & 30.00 & $.000 \mathrm{a}$ & $\mathrm{Na}$ \\
\hline Health cost (Rs/anim./day) & 0.50 & 0.00 & 4.00 & $.000 \mathrm{a}$ & $\mathrm{Na}$ \\
\hline Total expenditure (Rs/anim./day) & 67.11 & 14.66 & 138.11 & 18.49 & 0.014 \\
\hline Net return/anim. (Rs./day) & 12.98 & 10.30 & 53.10 & 28.67 & 0.000 \\
\hline Milk nourishment to the family (L/day) & 1.40 & 0.72 & 0.19 & 0.50 & 0.000 \\
\hline Dung production (Kg/day/anim.) & 19.45 & 3.16 & 25.23 & 3.55 & 0.004 \\
\hline Draught animal power (hrs/day) & 1.95 & 2.38 & 0.03 & 0.39 & 0.000 \\
\hline \multicolumn{6}{|l|}{ Without considering cost of fodder } \\
\hline Total feed cost (Rs/anim./day) & 13.35 & 8.08 & 49.70 & 12.64 & 0.000 \\
\hline Total expenditure (Rs/anim./day) & 23.85 & 8.08 & 83.68 & 12.62 & 0.000 \\
\hline Net return/anim. (Rs./day) & 56.24 & 15.75 & 107.53 & 33.43 & 0.000 \\
\hline
\end{tabular}

Table 2 Contribution of desi vs crossbred cows to the farmers livelihood

\begin{tabular}{|c|c|c|c|c|}
\hline \multirow[t]{2}{*}{ Type of contribution } & \multirow[t]{2}{*}{ Unit } & \multicolumn{2}{|l|}{ Values } & \multirow[t]{2}{*}{ P Value } \\
\hline & & Desi Cows & Crossbred Cows & \\
\hline \multirow[t]{3}{*}{ Income from cows } & Net return/anim./day (Rs.) & 12.98 & 53.10 & 0.000 \\
\hline & Net return/farm/day (Rs.) & 27.18 & 91.62 & 0.000 \\
\hline & Net return/L (Rs.) & 3.00 & 5.69 & 0.003 \\
\hline Income from cows & Net return/anim./day (Rs.) & 56.24 & 107.53 & 0.000 \\
\hline \multirow{2}{*}{$\begin{array}{l}\text { (Without considering cost } \\
\text { of fodder) }\end{array}$} & Net return/farm/day (Rs.) & 114.01 & 182.48 & 0.011 \\
\hline & Net return/L (Rs.) & 14.03 & 11.93 & 0.000 \\
\hline \multirow[t]{3}{*}{ Nourishment to the Family } & Protein (gm/day/family) & 44.90 & 5.92 & 0.000 \\
\hline & Fat (gm/day/family) & 57.52 & 7.59 & 0.000 \\
\hline & Calcium (mg/day/family) & 1683.60 & 222.00 & 0.000 \\
\hline \multirow[t]{3}{*}{ Nutrients to the Farm } & $\mathrm{N} \mathrm{kg} /$ year & 56.79 & 73.66 & 0.004 \\
\hline & P kg/year & 28.40 & 36.83 & 0.004 \\
\hline & $\mathrm{K} \mathrm{kg} /$ year & 113.59 & 147.33 & 0.004 \\
\hline Generating Employment & Man days/year & 42.34 & 80.02 & 0.000 \\
\hline Security for Uncertainties & Percentage & 18.83 & 78.00 & 0.000 \\
\hline Status Symbol & Percentage & 26.33 & 81.00 & 0.000 \\
\hline
\end{tabular}


Security for uncertainties and status symbol was more in case of crossbred cows $(78 \%$ \& $81 \%$, resp.) as compared to desi cows (18.83\% \& $26.33 \%$, resp.). Similar contribution of livestock to the livelihood of farmers in Western Maharashtra has been assessed by Biradar et al. (2013), wherein contribution of livestock to the household income ranged from 18.60 to 33.90 per cent and 63 per cent of dairy farmers opined livestock farming is a symbol of higher social status and concluded that livestock system contributed economically and socially to enhance sustainable livelihoods. Chaminuka et al. (2013) studied the livelihood role of cattle in South Africa and revealed about 11 per cent of the local households owned cattle and cattle income constituted 29 per cent of total household income. The study inferred that cattle production has important livelihood roles, but is not sufficient as a driver of economic development. Radder et al. (2012) studied the livelihood systems of dairy farmers in Karnataka using NineSquare-Mandalas' model and revealed that dairy activities integrated into several other economic activities performed by households. The role of dairy varied from a major source of economic livelihood sustenance to the minor system of subsistence milk production. Income from dairy was the source for purchasing food grains and to meet family cash needs. The ' $F$ ' \& 'Chi-square' test was used to test the difference between the types of contribution perceived by farm households in case of desi and crossbred cows. Analysis showed that there was a significant difference between all types of contribution of desi and crossbred cows.

\section{Conclusion}

The significant differences in milk production parameters and components of livelihood security in case of desi and crossbred cows were due to low productivity in case of desi cows as compared to crossbred cows. Also, one of the reasons for greater contribution of crossbred cows to livelihood security was most efficient and scientific management as compared to desi cows. However, Protein, fat and calcium nourishment per animal to the family gm/day was more in case of desi cows $(44.90,57.52 \& 1.68$, respectively) as compared to crossbred cows $(5.92,7.59 \& 0.22$, respectively). The potential to enhance the productivity of the desi breeds of India through professional farm management and superior nutrition is immense. Desi cows productivity can be improved with organized breeding programs, better management practices along with crossbred cows to hasten the efficiency of milk production and livelihood security of resource poor farmers.

\section{References}

Biradar N, Desai M, Manjunath L, Doddamani MT (2013) Assessing contribution of livestock to the livelihood of farmers of Western Maharashtra. J Hum Ecol 41: 107-112

Chaminuka P, Udo HMJ, Eilers KCHAM, Zijpp AVD (2013) Livelihood roles of cattle and prospects for alternative land uses at the wildlife/ livestock interface in South Africa. Land use policy 38: 80-90

Gautam PL (2007) Livestock in green revolution. Agriculture Today 3: 26-27

GOI (2014) Rashtriya Gokul Mission, Department of Animal Husbandry Dairying and Fisheries, Ministry of Agriculture, Krishi Bhavan, Government of India, New Delhi, India

Government of Karnataka (2011) Population census-2011, Raithamitra, Karnataka State Department of Agriculture, retrieved from http:// raitamitra.kar.nic.in/stat/27.htm.

Gopalan C, Ramasastri BV, Balasubramanian SC (1971) Nutritional value of Indian foods. Hyderabad: ICMR

Kolekar DV, Chander M, Avhad SR, Bangar YC (2015) Milk production parameters perceived by dairy farmers under contract farming in Western Maharashtra. Indian J Dairy Sci 68: 180-183

Radder SK, Bhanja SK, Tripathi H (2012) Livelihood systems and clean milk production-A case study. Asian J Agric Food Sci 31: 47-51 